胃癌原発巣の占居部位および組織型からみた 遠隔臓器転移形式に関する研究

$$
\begin{aligned}
& \text { 東京医科歯科大学第 } 2 \text { 外科学教室 } \\
& \text { 仁瓶善郎宮永忠彦 } \\
& \text { 平山廉三浅野献一 } \\
& \text { 同 病理 } \\
& \text { 神山隆一松原修 } \\
& \text { 同 中検病理 } \\
& \text { 青望 }
\end{aligned}
$$

\title{
STUDIES ON THE MODE OF DISTANT ORGAN METASTASIS \\ BASED ON THE LOCATION AND HISTOLOGICAL TYPE OF PRIMARY LESION OF THE GASTRIC CANCER
}

\section{Zenro NIHEI, Tadahiko MIYANAGA, Renzo HIRAYAMA and Ken-ichi ASANO}

The 2nd Department of Surgery, Tokyo Medical \& Dental University

\section{Ryuichi KAMIYAMA and Osamu MATSUBARA}

The Department of Pathology, Tokyo Medical \& Dental University

\section{Nozomu AOKI}

Pathological Section, Central Medical Laboratory, Tokyo Medical \& Dental University

胃癌の治療成績が向上した今日, 再発の問題は, 臨床医に残された大きな課題である.われわれは教室 で経験した胃癌剖検例92例を分析し, 占居部位拉よび組織型と遠隔葴器転移々の関係を検討した。

遠隔藏器転移は43例 $(47 \%)$ に認め, 高分化型に多く, 占居部位との関俰はなかった。 また, 遠隔臓器 転移を臓器別に分類すると, 従来いわれているWalther の mechanical theory にあてはまらない転移形 式があり, とくに肺転移に注目し, その転移経路（門脈型, 奇静脈型, リンパ一血行型, リンパ行型）を 示した。

索引用語：胃癌遠隔臓器転移, 転移経路, 胃癌肺転移

\section{I. はじめに}

胃癌の治療成績は, 手術々式の拡大, 化学療法, 免疫 療法の進歩とあいまって, 胃癌全体に対する早期胃癌の 占める率が高くなり, 著しく向上したが, 進行癌につい、

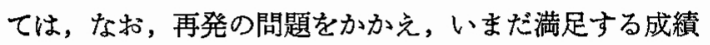
を得るに至っていない，そこで，再発形式について検討 を加えることは, 進行胃癌治療上重要な問題である. 遠 隔転移には, 血行性転移, リンパ行性転移, 腹膜播種の 3経路があるが，今回われわれは，血行性転移形式とし
ての遠隔藏器転移について, 剖検例を用いて, 胃癌の局 在扣よび組織型との関係を検討したので報告する.

\section{II. 症例の分析}

1. 検索対象

1955年より1975年までの21年間に教室で経験した胃癌 剖検例は92例で, 表 1 に示すごとく, 男性66例, 女性26 例, 年齡分布は20歳より82歳までで平均年龄53歳であっ た。

92例を分析すると, 表 2 に示すごとく，胃切除後再発 
表 1 彨嵒剖検例の性別と年龄

\begin{tabular}{|c|c|c|c|}
\hline 年 跉 性 別 & 男 & 女 & 計 \\
\hline $20-29$ & 3 & 1 & 4 \\
\hline $30-39$ & 8 & 5 & 13 \\
\hline $40 \sim 49$ & 9 & 6 & 15 \\
\hline $50 \sim 59$ & 20 & 11 & 31 \\
\hline $60-69$ & 20 & 3 & 23 \\
\hline $70 \sim 79$ & 4 & & 4 \\
\hline $80-$ & 2 & & 2 \\
\hline 計 & 66 & 26 & 92 \\
\hline 平均年齢 & 54.4 & 47.7 & 52.5 \\
\hline
\end{tabular}

表 2 胃癌剖検例の内訳

\begin{tabular}{|c|c|}
\hline 胃切除後再発死亡群 & 40 \\
\hline 原発巣非妇除群 & 26 \\
\hline 非手怯 湖 & 17 \\
\hline 原発巣切除後直接死亡群 & 9 \\
\hline 部 & 92 \\
\hline
\end{tabular}

死亡群40例, 単開腹・吻合術・瘦造設術後の原発栄非切 除群26例, 非手術群17例, および原発巣切除後直接死亡 群 9 例であった.

胃切除後再発死亡群, 原発巣非切除群, および非手術 群は, 剖検時の転移像は, 死因から考元て進行高度の胃 癌である.これに反して, 原発巣切除後直接死亡群は, その死因から考えて，転移巣はそれほど進行していな い. 原発巣切除後直接死亡群 9 例中 $\mathrm{C}$ 群が 3 例を占め, これはC群12例の25\%を占めていた，したがって，いず れも進行癌であるがC 群においては転移形成の時期から みて，他群と多少条件が異なることはいなめない。

組織型は, 高分化型 (乳頭腺癌, 管状腺癌) と, 低分 化型 (低分化腺癌, 印環細胞癌, 未分化癌) に分類し, 原発栄において両型が混在している場合には，胃癌取扱 い規約"にしたがい predominant な組織型をもって分類 した.すなわち，高分化型35例，低分化型57例であっ た. 表 3 に示す如く，高分化型は高齡者に多く，低分化 型は若年者に多くみられた。

占居部位は，胃癌取扱い規約にしたがい，胃を A, M, C に分けると, 表 4 に示すごとく, 主たる占居部位がA にあるもの A群は43例 (47\%),MにあるものM群は11例 (12\%),CにあるむのC群は12例 (13\%) で，腫瘍が全 胃にまたがるものをT群とすると，T群26例（28\%）で あった。
表 3 胃癌剖検例の組織型と年齢

\begin{tabular}{|c|c|c|c|}
\hline 年踰 組織型 & 高分化型 & 低分化型 & 塾 \\
\hline $20-29$ & & 4 & 4 \\
\hline $30 \sim 39$ & 1 & 12 & 13 \\
\hline $40 \sim 49$ & 5 & 10 & 15 \\
\hline $50 \sim 59$ & 14 & 17 & 31 \\
\hline $60 \sim 69$ & 11 & 12 & 23 \\
\hline $70 \sim 79$ & 3 & 1 & 4 \\
\hline $80 \sim$ & 1 & 1 & 2 \\
\hline it & 35 & 57 & 92 \\
\hline 平均年踚 & 57.7 & 49.3 & 52.5 \\
\hline
\end{tabular}

表 4 局在と組織型との関係

\begin{tabular}{|c|c|c|c|}
\hline loj 在: & 高分化型 & 低分化型 & it \\
\hline$T$ & 6 & 20 & 26 \\
\hline A & 21 & 22 & 43 \\
\hline M & 3 & 8 & 11 \\
\hline c & 5 & 7 & 12 \\
\hline iो & 35 & 57 & 92 \\
\hline
\end{tabular}

表 5 局在・組織型と遠隔葴器転移率

\begin{tabular}{|c|c|c|c|}
\hline 尚 $\mathrm{At}$ 組織型 & 高分化型 & 低分化型 & 計 \\
\hline $\mathrm{T}$ & $4 / 6(66.7)$ & $8 / 20(40.0)$ & $12 / 26(46.2)$ \\
\hline A & $11 / 21(52.4)$ & $9 / 22(40.9)$ & $20 / 43(46.5)$ \\
\hline M & $3 / 3(100)$ & $3 / 8(37.5)$ & $6 / 11(54.5)$ \\
\hline C & $4 / 5(80)$ & $1 / 7(14.3)$ & $5 / 12(41.7)$ \\
\hline 計 & $22 / 35(62.9)$ & $21 / 57(36.8)$ & $43 / 92(46.7)$ \\
\hline
\end{tabular}

各占居部位における組織型の頻度は, 表 4 に示すごと く、いずれの部位においても低分化型が多く，全胃にま たがるТ群ではとくに著明であった。

\section{2. 遠隔臟器転移}

遠隔蔵器転移陽性例は，92例中43例（47\%）であっ た。

各因子別に，その陽性率を検討すると，性別では，男 珄65例中32例 (49\%),女性27例中11例 (41\%) と差はな く, 平均年龄は54.4歳で, 男性平均年跉は57.5歳, 女性 のそれは45.4歳であった。

組織型との関係では，表 5 に示すごとく，高分化型35 例中22例 $(63 \%)$ ，低分化型57例中21例 (37\%) で，高分 化型に高い陽性率をみた。 
占居部位との関係は，T群 26 例中 12 例 $(46 \%), \mathrm{A}$ 群 43 例中 20 例 $(47 \%), \mathrm{M}$ 群 11 例中 6 例 $(55 \%), \mathrm{C}$ 群 12 例中 5 例 $(42 \%)$ と各群で陽性率に著差を認めないが，表 5 に 示すごとく，いずれの部位に朔いても高分化型に陽性率 が高かった。

次に, 遠隔藏器転移を, 肝臓, 肺藏 その他の臓器の 3 群に分けて検討した. すなわち，遠隔䐵器転移陽性 43 例を，その転移巣の局在により分類すると，表 6 に示す ごとく，肝転移陽性は30例 (69\%)，丂ち肺転移を伴って いるもの18例, 伴っていないるの12例, 肝転移陰性は13 例 $(31 \%)$, 万ち肺転移陽性例は 8 例で，他の 5 例は, 肺 転移子認めず，その他の臟器のみに転移を認めたもので あった。

組織型との関保は, 表 $7 \cdot 8$ 亿示すごとく, 高分化型 では22例中19例（86\%）飞肝転移を認めたのに対し，低 分化型の肝転移陽性例は21例中 11 例 (52\%) であった。 一方，肺転転移陽性例は，高分化型では14例 $(64 \%)$,低 分化型では12例 $(57 \%)$ であった.さらに肺転移陽性例 を分析すると，高分化型では14例中12例（86\%）飞同時 に肝転移を認めたのに反し，低分化型では，䀒転移を伴 った肺転移陽性例は，12例中 6 例 (50\%) であった。

占居部位との関係をみると, 表 $9 \cdot 10 \cdot 11 \cdot 12$ 亿示す

表 6 遠隔喴器転移の臓器別分類

\begin{tabular}{c|c|c|c}
\hline 肺転移 $^{\text {肝枟移 }}$ & + & - & 計 \\
\hline+ & 18 & 8 & 26 \\
\hline- & 12 & 5 & 17 \\
\hline it & 30 & 13 & 43 \\
\hline
\end{tabular}

表 7 遠隔藏器転移の臟器別分類：高分化型

\begin{tabular}{c|r|r|r}
\hline 肺転移 肝転移 & + & - & 計 \\
\hline+ & 12 & 2 & 14 \\
\hline- & 7 & 1 & 8 \\
\hline 計 & 19 & 3 & 22 \\
\hline
\end{tabular}

表 8 遠隔臓器転移の臟器別分類：低分化型

\begin{tabular}{c|c|c|c}
\hline 肺転移 $^{\text {肝転移 }}$ & + & - & 計 \\
\hline+ & 6 & 6 & 12 \\
\hline- & 5 & 4 & 9 \\
\hline 計 & 11 & 10 & 21 \\
\hline
\end{tabular}

表 9 遠隔臓器転移の臓器別分類：T 群

\begin{tabular}{|c|c|c|c|}
\hline 肺転移 肝転移 & + & - & it \\
\hline+ & 3 & 4 & 7 \\
\hline- & 3 & 2 & 5 \\
\hline 計 & 6 & 6 & 12 \\
\hline
\end{tabular}

表10 遠隔缄器転移の葴器別分類：A 群

\begin{tabular}{c|c|c|c}
\hline 肺転移 辻転移 & + & - & 計 \\
\hline+ & 10 & 2 & 12 \\
\hline- & 6 & 2 & 8 \\
\hline 計 & 16 & 4 & 20 \\
\hline
\end{tabular}

表11 遠隔藏器転移の臓器別分類：M群

\begin{tabular}{c|c|c|c}
\hline 肺転移 肘転移 & + & - & it \\
\hline+ & 2 & 1 & 3 \\
\hline- & 2 & 1 & 3 \\
\hline i! & 4 & 2 & 6 \\
\hline
\end{tabular}

表12 遠隔蔵器転移の葴器別分類：C 群

\begin{tabular}{c|c|c|c}
\hline 肺転移 䏚転移 & + & - & it \\
\hline+ & 3 & 1 & 4 \\
\hline- & 1 & 0 & 1 \\
\hline it & 4 & 1 & 5 \\
\hline
\end{tabular}

ごとく，肝転移陽性率は，T群では12例中 6 例 (50\%) であるのに対し，A，M，C 群では各々80\%，67\%，80 \%と高率であった．肺転移陽性例は，C群で 5 例中 4 例 （80\%）と多いが，他群では陰性例との間には著差を認 めなかった．A群では，肺転移陽性で肝転移を同時に認 める例が多かった。

3. 肝転移陰性・肺転移陽性例の検討

肝転移陰性, 肺転移陽性例は 8 例で, その内訳は，表 13に示すごとく, 高分化型 2 例, 低分化型 6 例であり, 占居部位は, $\mathrm{T}$ 群 4 例, $\mathrm{A}$ 群 2 例, M群, C 群各 1 例す つであった. 肺転移巣は, 高度 4 例, 中等度 1 例, 顕微 鏡にて初めて発見されたもの 3 例であった. 組織所見よ り，転移巣に叔ける腫場細胞の存在部位をみると，主と して血管内に存在するもの 5 例, リンパ管内に認めるも の 2 例，両者に認められるるの 1 例である。維隔りンパ 節を検索すると， 8 例中 5 例 $(63 \%)$ 飞転移を認めた. 
表13 肝転移陰性:, 肺転移陽性例

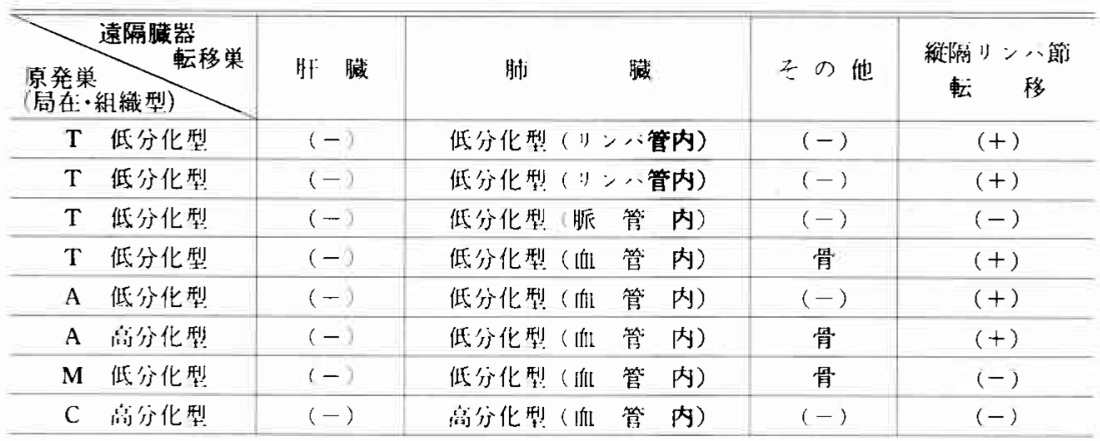

表14日ン八: 行性:転移陵性:例

\begin{tabular}{|c|c|c|c|c|}
\hline 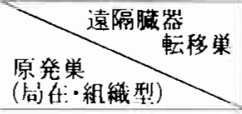 & 脿 & 肺 & 与の他 & $\begin{array}{c}\text { 縦隔リン八節 } \\
\text { 転 移 }\end{array}$ \\
\hline $\mathrm{T}$ 低分化型 & $(-)$ & $\begin{array}{c}\text { 低分化型 } \\
(\text { ）管內） }\end{array}$ & $(-)$ & $(+)$ \\
\hline $\mathrm{T}$ 低分化型 & $(-)$ & $\begin{array}{c}\text { 低分化型 } \\
\text { (リン管内) }\end{array}$ & $(-)$ & $(+)$ \\
\hline A 低分化型 & $\begin{array}{c}\text { 低分化型 } \\
\text { (リンハ管內) }\end{array}$ & $\begin{array}{c}\text { 低分化型 } \\
(\text { ）：管内） }\end{array}$ & 腎·副腎 & $(+)$ \\
\hline A 低分化型 & $\begin{array}{c}\text { 低分化型 } \\
\text { (リン心管闪) }\end{array}$ & $\begin{array}{l}\text { 低分化型 } \\
\text { (Ifll 管 }\end{array}$ & 媐 & $(+)$ \\
\hline
\end{tabular}

また, 肺以外の臓器にも転移を認めたものは 3 例で, そ の部位はいずれも骨䯣であった。

4. リンパ行性遠隔臓器転移陽性例の検討

遠隔葴器転移陽性例のうち, 血管内に腫湯を認めず, リンパ管内にのみ認めるリンパ行性経路による転移を, 4 症例 5 病巣に認めた。すなわち，表14亿示すごとく， 肺臓への 3 病巣, 肝葴への 2 病巣であり, 組織型は, 原 発巣, 転移巣とも低分化型であった．肺蔵に転移を認め たものの原発巣局在は T群, 肔臓に認めたるののそれは A群であった. なお, 肺蔵にリンパ行性転移をきたした 3 例は，全て縦隔リンパ節転移陽性であった。

\section{III. 考 察}

胃癌の治療成績は，早期診断の 向上，手術適応の扗 大, および補助療法の進歩により著しい向上をみてい る. しかしながら, 再発の問題は, その機序の解明が多 くの先人達により成されているにすかかわらず, 未解決 の部分が数多く残されており，古くて新しい問題である といえる、したがって，胃癌の再発拉よび転移を検討す ることは，治療上意義あるすのと考える．われわれは， 今回教室で経験した胃癌剖検例を用いて, 術前に比較的 得やすい因子，すなわち，原発巣の占居部位扰よび組織 型と, 遠隔藏器転移との関係について検討を加えた。
胃癌再発は，一般に局所再発と遠隔転移に分けられ， 遠隔転移形式はさらに，血行性転移，リンパ行性転移， 腹膜播種に分類されている ${ }^{2)}$ が，臓器再発に関しては, 岩永 ${ }^{3)}$ も指摘するように，その転移経路に関しては一概 に論じ得ないことがある．胃癌取扱い規約にも，血行性 転移の項はなく，肔転移といら臟器による分類となって いる. 臨休医の課題は, 完成された転移巣の治療にとど まらず，その経路を知り，再発を予防することにある。 われわれは，この目的のため，転移経路を再検討し，肝 缄, 肺蔵, その他諸臓器の遠隔転移をあえて, 「血行性 転移」とせず，「遠隔臓器転移」とした。

胃癌の組織型は一般に，幽門前庭部には高分化型，噴 門部には低分化型が多いとされている4が，われわれの 症例では逆であり, 占居部位別の遠隔蔵器転移を考察す るに際し，組織型の影響は無視し得ると考えた。

検索材料の平均年齢は53歳, 遠隔藏器転移陽珄例のそ れは54歳で，遠隔葴器転移は年齢と関係がない。

男女では，われわれは遠隔隔葴器転移に著差を認めな かったが，西ららは，手術時に男性に肝転移を多く認 め，男性に高分化型癌が多いことをその理由としてい る.われわれの例でも，男性66例中低分化型38例（58 $\%$ ，女性26例中19例（70\%）と，女性に低分化型を多く 
認めたが，かならずしも女性に遠隔缄器転移が少ないと はい兊なかった。

一方, 組織型と遠隔臟器転移との関係は, 高分化型で 60\%，低分化型で37\%と，高分化型飞高い陽性率を認め た。

勿論，先に述べたごとく，原発巣に分化度の異なる 癌組織型が 混在している場合，かならずしも predominant な組織型が転移をきたすとは限らず，原発巣での 劣性の組織型が転移栄において優位を占めることはまれ ならず経験するし，考慮に入れなければならない，した がって, 厳密には原発巣が単一の組織型のみで構成され ているるのについての検索が必要である ${ }^{6)}$.

占居部位と遠隔臟器転移の関係は，C群にやや低い が，これは先述のごとく原発巣切除後直死例が多いため であるら.しかし，T，A，M 群問に著差のないこと， すなわち 群にとくに遠隔藏器転移率が 高くないこと は，根本ら”の指摘するように，腫煌の広がりは遠隔臓 器転移に影響を与えないことを示唆している。

癌の血行性転移を論ずるにあたり，原発巣の循環系に おける位置を基準とした Walther の mechanical theory による分類 ${ }^{8}$ が1つの手がかりとなる。この分類にした がらと, 胃は門脈型に属し、ここより遊離した腫痬細胞 あるいは腫瘍塊は, 肝荿で第1の濾過をうけ，したがっ て肝臓に第 1 の転移巣をつくることが多く,ささらに, あ たかもこの肝転移巣が原発巣であるのと同様な転移経路 を辿って肺で第 2 の濾過をらけ転移巣をつくるのが原則 である。

われわれは, 遠隔臟器転移巣を, 肝臓, 肺臓, その他 の臓器 (骨簿, 腎, etc.) の3つに大別し, とくに上述 の mechanical theoryで, いわゆる filter といわれ る, 肝臓, 肺藏に注目して転移巣の分類を行った。ただ し, 腹膜播種により横隔膜を介して胸腔に至り, 癌性胸 膜炎を呈した形のものは，腹膜播種の一型とみなし，遠 隔臓器転移の範围から除外した。

表15は，諸家の報告を少しく改変したものであるが， そのいずれに扎いても，Walther の分類にあてはまらな い転移形式が出現している．われわれの例でこれらをさ らに検討すると, 高分化型においては, 遠隔藏器転移陽 性22例中肝転移陽性例が19例（86\%）と高いが，低分化 型に打いては，肝転移を認めない遠隔葴器転移陽性例 が，21例中10例（48\%）を占め，低分化型では高分化型 より Walther の転移経路にあてはまりにくい転移像を 示すものが多かった。
表15 遠隔葴器転移の葴器別分類（但し，朋臓，

肺臓以外の諸蔵器は含まない)

\begin{tabular}{|c|c|c|c|c|c|}
\hline & 支告者 & 古野 ${ }^{9)}$ & 副島10) & Willis $^{11}$ & 著者ら \\
\hline \multirow{2}{*}{+} & + & 13 & 8 & 27 & 18 \\
\hline & - & 20 & 7 & 59 & 12 \\
\hline \multirow{2}{*}{-} & + & 11 & 2 & 8 & 8 \\
\hline & - & 27 & 4 & 80 & 54 \\
\hline
\end{tabular}

もちろん Walther 自身も, 門脈型に属する臓器より 極くまれには，乳び槽一一胸管一大静脈一一右心 肺といら肝淢を通過しない経路を辿ることを同時に示し ている.いずれにせよ，胃癌の遠隔臟器転移経路が，か ならずしも, 肝臟——肺臓——全身諸缄器といった単一 化された経路では説明しえず，いずれの癌がいずれの経 路をとるかについては，さらに検討の必要があると考兄 る.

剖検例では，転移の様相がその終末像を呈している訳 であるが，肺転移巣に打いてッンパ管内に腫煌を認めた あのがあった．すでに肺実質内に腫瘤を形成している転 移病巣では，その転移経路は推測の域を出ない，一方， リンパ管内あるいは血管内に腫湟細胞を認めても，それ が死隇するか, あるいは転移病巣として発育してゆくの かは不明であるが，転移経路を知る上では，すでに腫瘤 を形成した転移巣をもつものよりも，直接その経路を示 しているといら点で重要である.

中村ら ${ }^{12)}$ は, 胃癌の肝臓への転移は, 未分化型癌では リンパ行性に肝十二指腸靬帯より浸潤し，分化型癌では 問脈経由による転移が多いと指摘している，われわれの 肝リンパ行性転移も，いずれも低分化型であった。

以上の所見より, 胃癌が遠隔藏器転移をきたす経路と して，血行性のみならずッンパ行性のものも考虑に入れ る必要があると考劣る。

最後に，以上の所見より得られた知識を基にして，見 在われわれの考えている肺転移経路を示す（図1，2， $3,4)$.

1）門脈型：いわゆる Walther の型にあたる転移経 路で, 肝蔵で第 1 の濾過をうけ, 肺臓に第 2 の転移巣 を形成する型であり，多くはこの経路を巡ると考える。

2）奇静脈型：胃冠状静脈より食道静脈丵を通り, 奇 静脈より大结環系に入り, 肺転移栄巣を作る型であり, 解剖学的に噴門部の癌に多いと考える. 


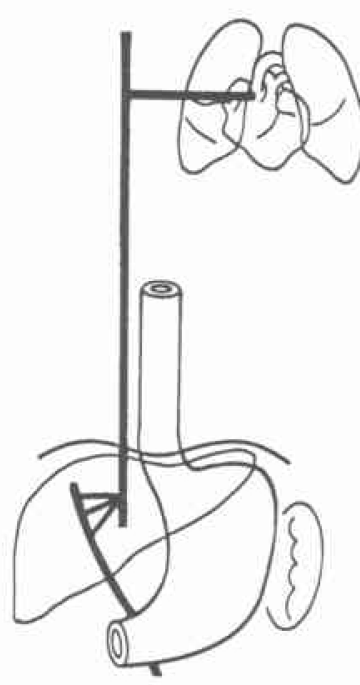

図1門脈型

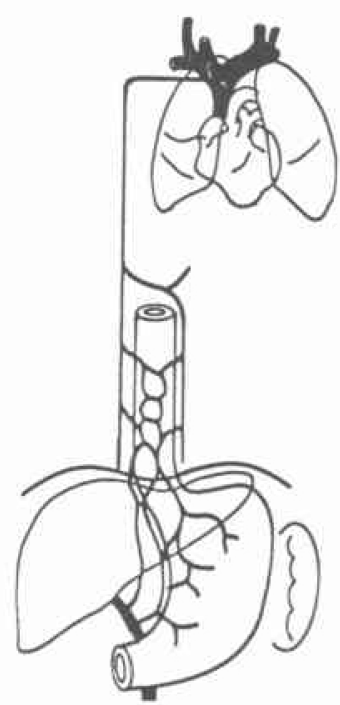

図 2 奇静眽型

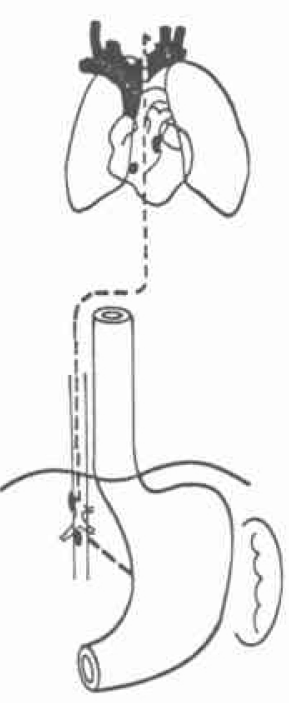

図3リンパ血行型

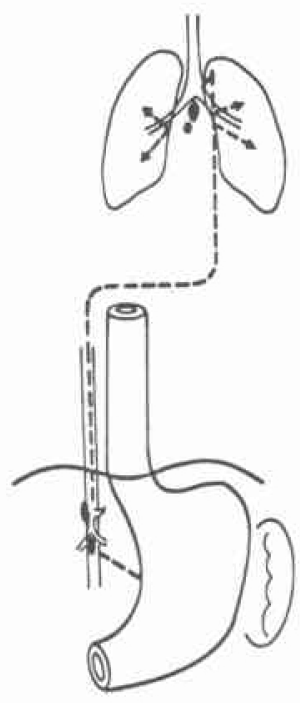

図 4 リンパ行型
3）リンハー一血行型：Walther がIVb として分類し たもので, 乳び槽より後綎隔を通り大静脈に入り, 肺転 移巣をつくる型.

4）リンパ行型：3）と同様, 後縱隔に至り, 肺門部リ ンパ節より逆行性に肺転移巣を作る型.

3）４）はいずれる，後縃隔リンパ節に転移を認めるこ とが条件となる。

\section{IV. 結 語}

1955年から1975年の 21 年間に教室で剖検された胃癌症 例92例を分析し, 遠隔蔵器転移を検討し, 次の結果を得 た.

1）高分化型35例，低分化型57例で，高分化型は高龆 者に多かった。

2) $\mathrm{A}$ 群44例, M群11例， C群12例， T群26例で, 各 占居部位における組織型はいずれも低分化型が多かっ た.

3）遠隔臟器転移は43例（47\%）飞認め，性別による 差はなく，年齢も影響を与えていなかった。

4）遠隔臓器転移陽性率は, 高分化型に高く, 腫煌の 占居部位とは特に関係を認めなかった。

5）遠隔藏器転移の内訳は，肝転移陽性肺転移陽性18 例, 肝転移陽性肺転移陰性 12例, 肝転移陰性肺転移陽性 8 例, 肝・肺以外の臓器にの久転移陽性 5 例であった。

6）肝転移肺転移ともに高分化型に陽性率が高いが,
肝転移を伴わない肺転移陽性例は，低分化型に多くみら れた。

7）肝転移陽性率は， $\mathrm{T}$ 群で低く，腫瘍の広がりと関 係ないことを示す，肺転移陽性率は，C群で高い。

8）肝転移陰性・肺転移陽珄例は 8 例で，低分化型に 多く，後緃隔リンパ節陽性は 5 例に認めた。

9）肝臓・肺臓のリンパ行性転移陽性例を 4 症例 5 病 巣に認めた．全て低分化型であり，肺臟に認める 3 例は 全例に後綎隔リンパ節転移を認めた。

10）癌性胸膜炎の型をとるものを除き，胃癌の肺転移 経路 (門脈型, 奇静脈型, リンパ——血行型, リンパ行 型）を示した。

（本論文の要旨は, 昭和53年 2 月第 11 回日本消化器外 科学会総会にて発表した。)

\section{文献}

1) 胃癌研究会稨：胃癌取扱い規約。金原出肘，東 京, 1976 .

2) 浜口栄祐, 他：癌の再発. 癌の臨床, 5 : 635 $-727,1959$.

3) 岩永 用：胃癌再発の分類とその問題点につい て. 臨外, 32:249-252, 1977.

4) 中村恭一：胃癌の病理. 金劳堂, 東京, 1972 .

5) 西満 正, 他 : 肝転移胃癌の臨床的研究. 癌の 臨床, 8：433-442, 1962.

6) 宮永忠彦, 他 : 胃切除後再発死亡例の剖検所見 からみた胃の再発形式と治療の反省。癌の臨 
床, $23: 1397-1403,1977$.

7) 根本 宏, 他 : 肝転移切除胃例 の検討 (会). 第18回骨癌研究会, 1972.

8) Walther, H.E.: Krebsmetastasen. Benno Schwabe, Basel, 1948.

9) 古野八郎：胃癌の転移に関する病理解剖学的知 見補遗. 医学研究, $27: 1496-1515,1956$.
10)副島一彦: 再発胃癌飞関する病理解剖学的知見 補遗. 福岡医誌, $55 ： 410-430 ， 1964$.

11) Willis, R.A.: The Spread of Tumors in the Human Body. Butterworth Co. Ltd., London, 1952.

12）中村恭一, 他：構造的にみた胃癌.臨床科学, $8: 1385-1396,1972$. 